\title{
Benthic $\mathrm{O}_{2}$ exchange across hard-bottom substrates quantified by eddy correlation in a sub-Arctic fjord
}

\author{
Ronnie N. Glud ${ }^{1,2,3, *}$, Peter Berg ${ }^{4}$, Andrew Hume ${ }^{1,4}$, Paul Batty ${ }^{2}$, Martin E. Blicher ${ }^{2}$, \\ Kunuk Lennert ${ }^{2}$, Søren Rysgaard ${ }^{2}$
}

\begin{abstract}
${ }^{1}$ Scottish Association for Marine Science, Dunstaffnage Marine Laboratory, PA37 1QA, Dunbeg, UK
${ }^{2}$ Greenland Climate Research Centre (c/o Greenland Institute of Natural Resources), Kivioq 2, PO Box 570, 3900 Nuuk, Greenland ${ }^{3}$ Southern Danish University, Institute of Biology and Nordic Center for Earth Evolution (NordCee), 5230 Odense M, Denmark ${ }^{4}$ Department of Environmental Science, University of Virginia, 291 McCormick Road, Charlottesville, Virginia 22904, USA
\end{abstract}

ABSTRACT: Oxygen exchange across the seabed is a key measure for quantifying benthic carbon turnover. However, technical limitations have restricted such measurements to sedimentary areas. Few assessments on hard-bottom substrates exist although such biotopes are frequent along many coastlines. In spring 2009, we used the non-invasive eddy correlation technique to quantify the in situ $\mathrm{O}_{2}$ exchange rate across 3 typical substrates in West Greenland: (1) in soft sediments, the $\mathrm{O}_{2}$ exchange in darkness averaged $2.0 \mathrm{mmol} \mathrm{m}^{-2} \mathrm{~h}^{-1}$. The rate exceeded the $\mathrm{O}_{2}$ exchange quantified from microprofile measurements by $80 \%$, but was not significantly different from parallel core incubations. (2) Measurements across consolidated sand and stones revealed a high activity with average $\mathrm{O}_{2}$ exchange similar to that of sedimentary areas. Despite being net heterotrophic, the benthic primary production on average amounted to $27 \mathrm{mmol} \mathrm{O} \mathrm{m}^{-2} \mathrm{~d}^{-1}$, which per unit area is similar to the pelagic gross production of the central fjord. Carbon fixed by benthic diatoms and coralline red algae was efficiently recycled by microbes or grazed by the abundant epifauna. (3) A vertical cliff covered with sea cucumbers also revealed high $\mathrm{O}_{2}$ consumption rates $\left(1.2 \mathrm{mmol} \mathrm{m}^{-2} \mathrm{~h}^{-1}\right)$. The $\mathrm{O}_{2}$ exchange derived from the eddy correlation approach exhibited pronounced shortterm variability reflecting the interplay of several dynamic controls, most importantly short-term variations in local hydrodynamics. All together, measurements across hard-bottom substrates revealed active benthic communities that mediate high carbon turnover rates.

KEY WORDS: Benthic photosynthesis · Microsensors · Remineralization - In situ technology - Psolus fabricii · Strongylocentrotus droebachiensis

Resale or republication not permitted without written consent of the publisher

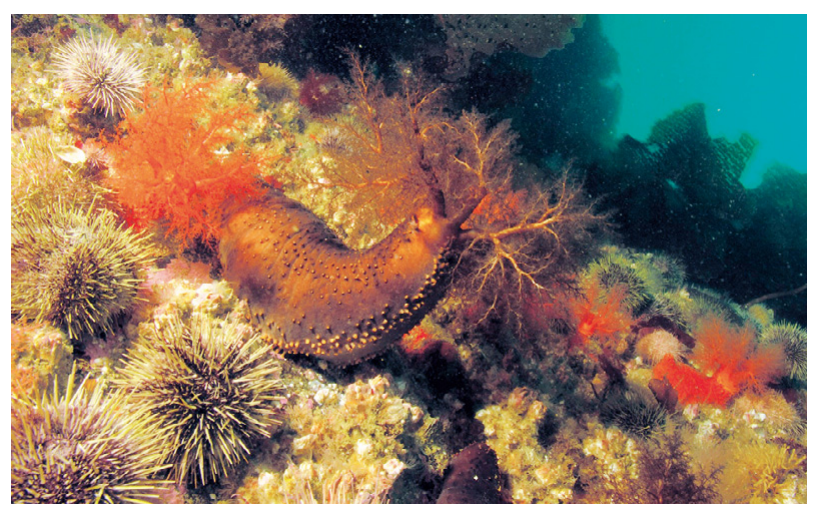

Aquatic eddy correlation measurements show that hardbottom communities recycle large quantities of organic material and play an important role in coastal carbon cycling.

Photo: G. Ehlme

\section{INTRODUCTION}

Aquatic sediments play a key role for the mineralization of organic material and regeneration of nutrients in coastal environments (Middelburg et al. 2008). Sediments also can host high phototrophic biomass that contributes significantly to the sustenance of coastal food webs (Jahnke et al. 2000, Glud et al. 2009). Most quantitative assessments of benthic production or degradation of organic material have relied on laboratory or in situ determinations of benthic $\mathrm{O}_{2}$ exchange rates (Glud 2008). These have either been determined using sediment enclosures or microprofile measurements, which generally are constrained to soft sediments. Only a few chamber or microelectrode investigations have been carried out in natural sandy 
environments, and in these cases they have been confined to relatively well-sorted sand (de Beer et al. 2005, Cook et al. 2007, Huettel et al. 2007, Glud et al. 2008). The difficulties of core sampling, chamber emplacement or sensor application on hard-bottom heterogeneous benthic substrates have left such environments practically unstudied in the context of organic carbon turnover although such benthic substrates are frequent in coastal habitats. Rocks, high currents, wave action, ice erosion, coarse glacial deposits, down slope transport of coarse unsorted erosion material and high densities of large-sized epifauna are characteristic and dominant features of many Arctic and sub-Arctic coastlines (Hop et al. 2002, Boertmann et al. 2009)

The introduction of the aquatic eddy correlation approach (Berg et al. 2003, Kuwae et al. 2006, Berg \& Huettel 2008, McGinnis et al. 2008) has made it feasible to non-invasively quantify the benthic $\mathrm{O}_{2}$ exchange of complex benthic surfaces. This derives the benthic $\mathrm{O}_{2}$ exchange rate at true in situ conditions from simultaneous recordings of the vertical flow velocity and the $\mathrm{O}_{2}$ concentration at a given point within the benthic boundary layer (Berg \& Huettel 2008). The approach imposes a minimum of disturbance to the ambient light field, the benthic substratum and the local hydrodynamics and it works equally well over soft- and hard-bottom substrates. Further, it integrates the activity of a larger area (i.e. 10 to $50 \mathrm{~m}^{2}$; Berg et al. 2007) than traditional measurements and can resolve fluxes down to at least $\sim 1 \mathrm{mmol} \mathrm{O}_{2} \mathrm{~m}^{-2} \mathrm{~d}^{-1}$ (Berg et al. 2009). At present, the current database on benthic exchange rates from marine environments derived from the eddy correlation only consists of 4 studies (Berg et al. 2003, 2009, Kuwae et al. 2006, Berg \& Huettel 2008), none of which include complex hard-bottom substrates.

The present study quantifies benthic $\mathrm{O}_{2}$ exchange rates of different shallow-water and hard-bottom substrates in a sub-Arctic fjord system, using the eddy correlation technique. Applicability of the approach to such environments is evaluated and the auto- and heterotrophic activities at the 5 measuring sites are discussed in the context of regional carbon cycling.

\section{MATERIALS AND METHODS}

Study site. The study was conducted in May 2009 within the Godthaabsfjord system in SW Greenland (Fig. 1). We measured across 5 different substrates (8 deployments) at depths of less than $20 \mathrm{~m}$, each representing common benthic environments of the Godthaabsfjord system, and of the sub-Arctic and Arctic in general (Fig. 1). These sites included: Stn 1, a cohesive silty-sand substrate; Stn 2, a mixed, consolidated coarse sand overlain by small stones covered with coralline red algae; Stn 3, a mixed, fine sand-shell substrate with high densities of the sea urchin Strongylocentrotus droebachiensis; Stn 4, similar to Stn 3, but with higher densities of coralline red algae; and Stn 5, a vertical rock wall at a depth of $\sim 17 \mathrm{~m}$ with high densities of the sea cucumber Psolus fabricii (Fig. 2). Basic station characteristics are given in Table 1. Variations of $\mathrm{O}_{2}$, temperature and salinity do not reflect analytical precision but variations in the local environment during the 6 to $22 \mathrm{~h}$ periods of sampling.

Fauna densities and photo-documentation of the seabed. At each station the seabed was photographed ( $\mathrm{n}=10$ to 20) (Fig. 2) using a submersible digital camera (Nikon D80 within a titanium casing, Ocean Imaging Systems) mounted on a metal frame. Here the camera shutter was activated by bottom contact of a lead weight. At Stn 5 the camera was diver operated and a rod was used to ensure a fixed distance to the vertical cliff during photography to scale photos. The density of identifiable faunal species was determined on the basis of the photographs, each covering an area between 0.38 and $1.05 \mathrm{~m}^{2}$, depending on the optical configuration of the camera. The silty sand of Stn 1 hosted little conspicuous epifauna and therefore no systematic photo-investigations were carried out, but sediment inspection was complemented by van Veen grabs ( $\mathrm{n}=$ 3 , each $0.1 \mathrm{~m}^{2}$ ). Samples were sieved through a $1.0 \mathrm{~mm}$ mesh and collected specimens were fixed in $6 \%$ boraxbuffered formaldehyde and transferred to $70 \%$ ethanol for later taxonomic determination.

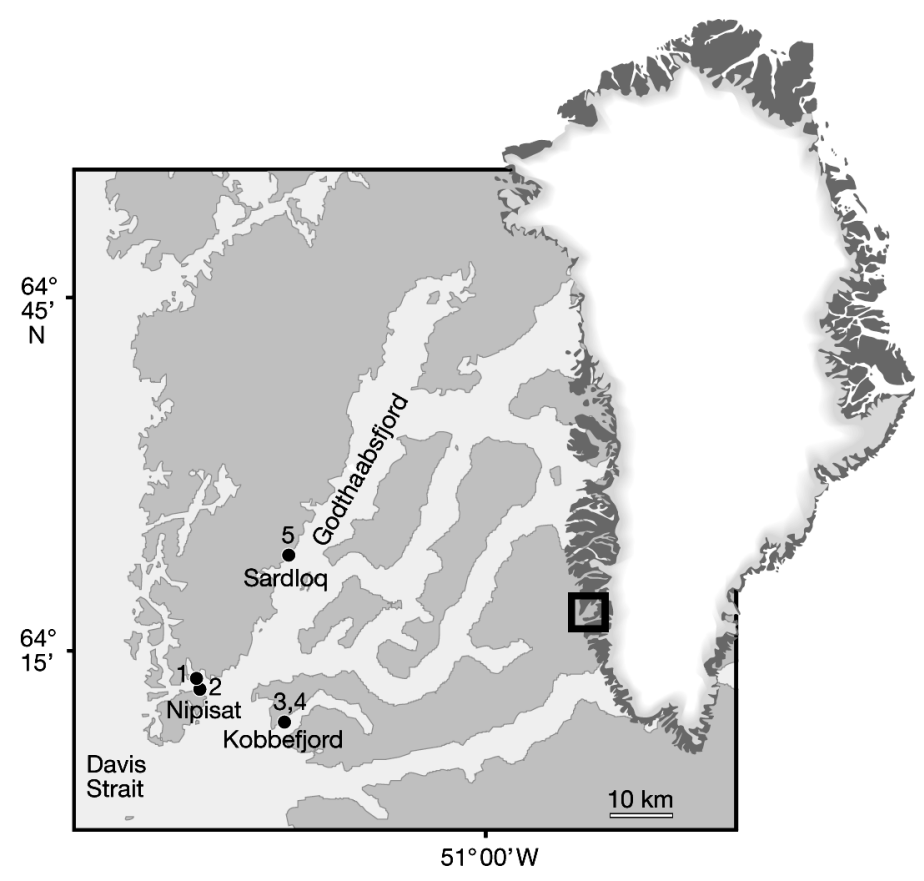

Fig. 1. Map indicating locations of deployments within the Godthaabsfjord system of Southwest Greenland 

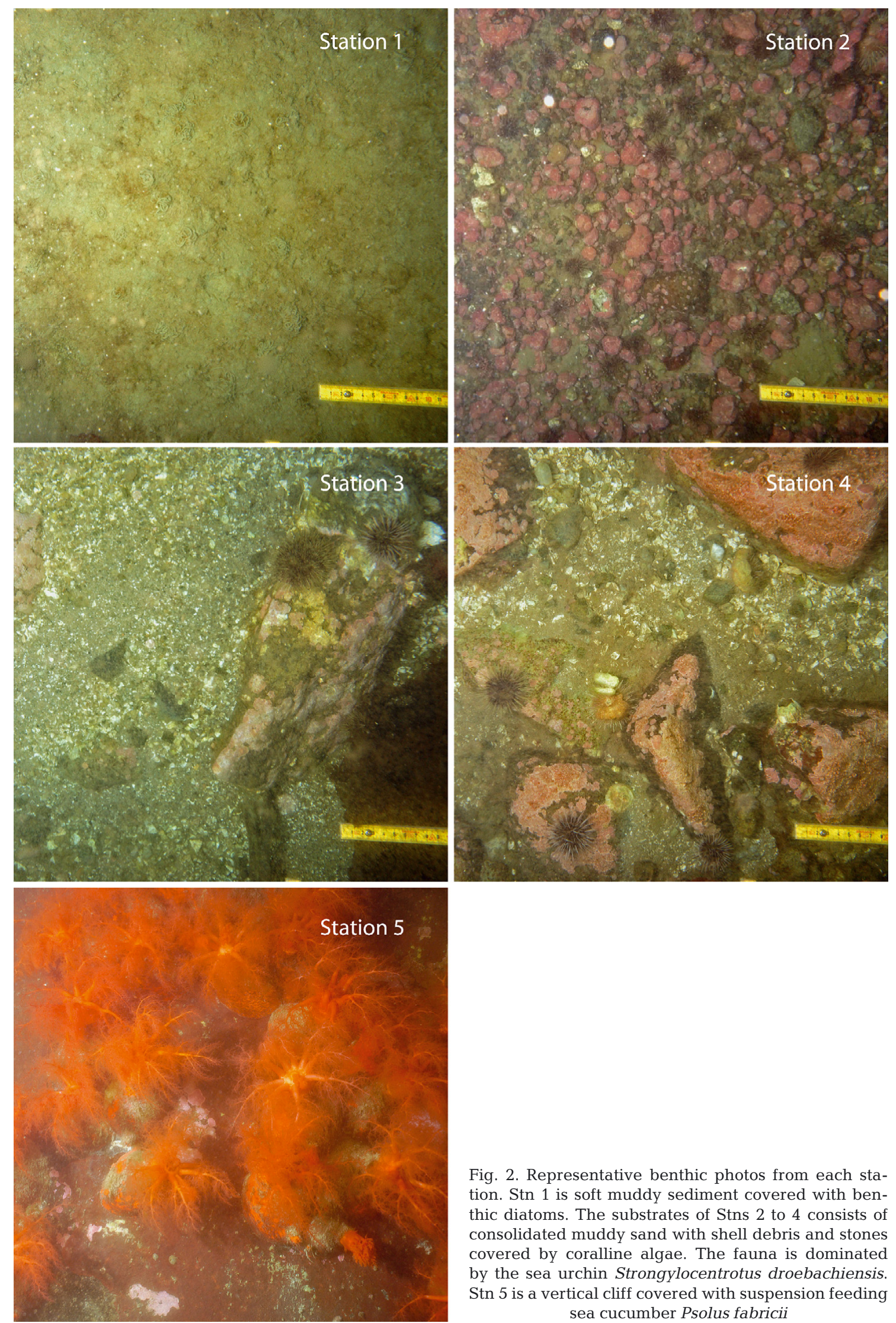

Fig. 2. Representative benthic photos from each station. Stn 1 is soft muddy sediment covered with benthic diatoms. The substrates of Stns 2 to 4 consists of consolidated muddy sand with shell debris and stones covered by coralline algae. The fauna is dominated by the sea urchin Strongylocentrotus droebachiensis. Stn 5 is a vertical cliff covered with suspension feeding sea cucumber Psolus fabricii 
Table 1. Station and deployment characteristics (mean \pm SD) for the 8 deployments (depl.). Stns 1 and 3 were investigated 3 and 2 times, respectively, while the remaining stations were visited only once. The tidal range during the study period was $\sim 3.5 \mathrm{~m}$ and depth values reflect mean during deployments

\begin{tabular}{|c|c|c|c|c|c|c|c|c|}
\hline & $\begin{array}{l}\text { Latitude } \\
\text { N }\end{array}$ & $\begin{array}{c}\text { Longitude } \\
\text { W }\end{array}$ & $\begin{array}{c}\text { Depl. } \\
\text { no }\end{array}$ & $\begin{array}{l}\text { Depth } \\
\text { (m) }\end{array}$ & $\begin{array}{l}\text { Temp. } \\
\left({ }^{\circ} \mathrm{C}\right)\end{array}$ & Salinity & $\begin{array}{c}\text { Oxygen } \\
\left(\mu \mathrm{mol} \mathrm{l}^{-1}\right)\end{array}$ & $\begin{array}{l}\text { Depl. time } \\
\text { (h) }\end{array}$ \\
\hline Stn 1 & $64^{\circ} 11.761^{\prime}$ & $51^{\circ} 54.607^{\prime}$ & $\begin{array}{l}3 \\
4 \\
8\end{array}$ & $\begin{array}{l}6.6 \\
6.5 \\
5.4\end{array}$ & $\begin{array}{l}1.6 \pm 0.1 \\
1.7 \pm 0.2 \\
3.0 \pm 0.4\end{array}$ & $\begin{array}{l}33.1 \pm 0.1 \\
33.1 \pm 0.0 \\
32.9 \pm 0.1\end{array}$ & $\begin{array}{l}363 \pm 5 \\
378 \pm 5 \\
424 \pm 5\end{array}$ & $\begin{array}{c}14.3 \\
0.8 \\
18.1\end{array}$ \\
\hline Stn 2 & $64^{\circ} 11.598^{\prime}$ & $51^{\circ} 54.529^{\prime}$ & 7 & 8.2 & $2.9 \pm 0.3$ & $33.0 \pm 0.0$ & $413 \pm 8$ & 12.5 \\
\hline Stn 3 & $64^{\circ} 08.129^{\prime}$ & $51^{\circ} 39.386^{\prime}$ & $\begin{array}{l}1 \\
5\end{array}$ & $\begin{array}{l}6.3 \\
6.1\end{array}$ & $\begin{array}{l}0.3 \pm 0.1 \\
0.3 \pm 0.1\end{array}$ & $\begin{array}{l}33.0 \pm 0.1 \\
33.0 \pm 0.0\end{array}$ & $\begin{array}{l}346 \pm 7 \\
349 \pm 7\end{array}$ & $\begin{array}{c}6.7 \\
19.6\end{array}$ \\
\hline Stn 4 & $64^{\circ} 08.121^{\prime}$ & $51^{\circ} 39.348^{\prime}$ & 2 & 11.7 & $0.3 \pm 0.1$ & $33.0 \pm 0.1$ & $344 \pm 6$ & 21.9 \\
\hline Stn 5 & $64^{\circ} 21.386^{\prime}$ & $51^{\circ} 40.508^{\prime}$ & 6 & 17.8 & $1.8 \pm 0.1$ & $32.7 \pm 0.0$ & $416 \pm 14$ & 12.1 \\
\hline
\end{tabular}

Laboratory-determined $\mathrm{O}_{2}$ exchange rates. Sediment core sampling was only possible at Stn 1 , and a total of 6 sediment cores (inner diameter $5.3 \mathrm{~cm}$ ) were recovered using a Kajak-sampler (KC-Denmark). The cores were transported to the laboratory in thermoinsulated containers, where they were uncapped and submerged in bottom water from the sampling site. The water was kept at in situ temperature and air saturation. A rotating Teflon coated magnet attached to the inner wall of each core ensured a good mixing and exchange between the water phase of the cores and the exterior seawater. After overnight pre-incubation, $\mathrm{O}_{2}$ microprofiles and total $\mathrm{O}_{2}$ exchange rates were obtained. In short, 2 to $4 \mathrm{O}_{2}$ microprofiles were measured in each of the 6 cores using Clark type microelectrodes with an internal reference and a guard cathode (Revsbech 1989). The microelectrodes had tip diameters of 3 to $20 \mu \mathrm{m}$, stirring effects $<1 \%$, and a $90 \%$ response time of $<0.3 \mathrm{~s}$ (Gundersen et al. 1998). The profiles were measured at a depth resolution of 100 to $200 \mu \mathrm{m}$ in spots that were visibly unaffected by faunal activity. The microelectrodes were positioned by a motorized micromanipulator. Sensor current was measured by a picoammeter connected to an A-D converter, which transferred the signals to a computer (Revsbech \& Jørgensen 1986). Microprofiles had 2 inherent calibration points: the reading in the overlying water with a known $\mathrm{O}_{2}$ concentration, and the reading in the anoxic sediment. After microprofiling, sediment cores were capped with a gas-tight glass plate, leaving an internal water height of 8 to $12 \mathrm{~cm}$. On the underside of the glass plate an $\mathrm{O}_{2}$ PreSens ${ }^{\mathrm{TM}}$ optode patch (diameter $5 \mathrm{~mm}$ ) was attached, to allow non-intrusive periodic measurement of oxygen consumption in conjunction with a PreSens ${ }^{\mathrm{TM}}$ optical fibre cable and a Fibrox ${ }^{\mathrm{TM}}$ (model 3) oxygen meter connected to a computer. During incubations, 4 to 6 recordings were obtained at a regular interval in each core while the attached magnets continued to stir the overlying water phase (one core did not provide consistent results probably due to resuspension during incubations, and these data were excluded). All measurements were done in darkness. After flux measurements, sediment cores were sectioned for porosity determinations that were derived from a measured weight loss after $24 \mathrm{~h}$ at $100^{\circ} \mathrm{C}$ and the determined specific density.

Diffusive $\mathrm{O}_{2}$ exchange (DOE) of the sediment was calculated from the $\mathrm{O}_{2}$ microprofiles as: $\mathrm{DOE}=-D_{\mathrm{o}}$ $\mathrm{d} C(z) / \mathrm{d} z$, where $D_{\mathrm{o}}$ is the temperature- and salinitycorrected molecular diffusion coefficient of $\mathrm{O}_{2}$ and $C$ is the $\mathrm{O}_{2}$ concentration at a given depth $(z)$ within the diffusive boundary layer (DBL). $D_{0}$ was taken from Broecker \& Peng (1974) and was temperature corrected as described by Li \& Gregory (1974). The total $\mathrm{O}_{2}$ uptake rate (TOU) was calculated from the linear $\mathrm{O}_{2}$ decrease measured during the whole core incubation (Glud et al. 2003).

Eddy correlation measurements. A small stainless tripod (side length $1.3 \mathrm{~m}$. height $0.9 \mathrm{~m}$ ) held a small CTD (Seabird SBE 19Plus) was equipped with sensors logging temperature, conductivity, $\mathrm{O}_{2}$ and photosynthetically active scalar radiation (PAR; QSP-2300L) irradiance every $5 \mathrm{~min}$. A vertically aligned acoustic Doppler velocimeter (Vector, Nortek; referred to as the ADV) was placed centrally in the frame in such way that the cylindrical measuring volume $(1.5 \times 0.6 \mathrm{~cm})$ located along the ADV centreline was situated 8 to $10 \mathrm{~cm}$ above the seabed during deployments. The ADV was interfaced with a custom-built pressurecompensated $\mathrm{O}_{2}$ microelectrode (previous section) via a submersible picoammeter (Unisense). The picoammeter housing was positioned at a $45^{\circ}$ angle relative to the ADV centreline and the position of the microelectrode tip adjusted to the edge of the ADV measuring volume (Berg et al. 2003). The ADV and the $\mathrm{O}_{2}$ microelectrode signals were sampled at a frequency of $32 \mathrm{~Hz}$ in bursts consisting of 14.5 min sampling followed by a $0.5 \mathrm{~min}$ 'sleep' period. Total deployment times ranged 
from 18 to $22 \mathrm{~h}$, but the majority of the deployments were truncated by microelectrode breakage caused by debris floating along with the bottom current. The periods of successful data recording ranged from 0.8 to $21.9 \mathrm{~h}$ with an average measuring period of $\sim 14 \mathrm{~h}$ (Table 1 ).

The zero current of the oxygen microelectrode was determined prior to each deployment by dipping the sensor tip in an anoxic dithionite solution kept at $0^{\circ} \mathrm{C}$. Further, the sensor signal during deployments was calibrated against the bottom-water $\mathrm{O}_{2}$ concentration determined by 3 approaches: (1) measured in sampled bottom water with a handheld Hach HQ40d optical DO meter (Hach Company), (2) by Winkler titration, and (3) by the polarograhic DO sensor on the CTD attached to the measuring tripod. These values did not deviate by more than $3 \%$. Continuous recordings of the bottom-water characteristics (temperature, salinity, $\mathrm{O}_{2}$ concentration) reflected gradual changes related to tidal flow and light availability. Variations in temperature and salinity were considered insignificant, while variations in the bottom-water $\mathrm{O}_{2}$ concentration (Table 1) were accounted for during eddy flux calculations.

At Stns 1 to 4, the eddy correlation tripod was deployed using a winch. At the rock wall face (Stn 5), the tripod was attached to the wall by bolts drilled into to the wall by a diver. During this operation great care was taken not to disturb the natural epifauna. We chose an area ( $~ 80 \mathrm{~m}$ wide and $\sim 10 \mathrm{~m}$ high) covered by epi-macrofauna but without any significant topography. Due to the relative large size of the sea cucumbers, we adjusted the measuring volume to $16.7 \mathrm{~cm}$ away from the wall.

Eddy correlation fluxes of $\mathrm{O}_{2}$ were calculated based on the values of the 2 correlating parameters; vertical velocity and $\mathrm{O}_{2}$ concentration, as described in Berg et al. (2003, 2009). In short, the original $32 \mathrm{~Hz}$ recordings were averaged to $16 \mathrm{~Hz}$ data to reduce the signal to noise ratio. Subsequently, least-squares linear regression fits were used to define the mean vertical velocity and the mean $\mathrm{O}_{2}$ concentration in each of the 14.5 min measuring segments (bursts). Then instantaneous deviations from these means were determined and multiplied to give the instantaneous $\mathrm{O}_{2}$ fluxes, which were finally averaged to give 1 value for each 14.5 min long burst.

Each time series of instantaneous velocities of $\mathrm{O}_{2}$ concentrations and fluxes was carefully examined for 'unnatural' disturbances, typically caused by a small piece of organic material hitting the microelectrode tip, or less frequently, a larger piece of debris momentarily corrupting the velocity readings. Disturbances give rise to a temporary change in an $\mathrm{O}_{2}$ reading that most often lasts 'several or many' data points and thus affects the definition of the mean $\mathrm{O}_{2}$ concentration, and ultimately the flux extraction. Such disturbances 'or bad data sequences' were identified by visually inspecting plots of data series. In this process, and in addition to the instantaneous velocities and $\mathrm{O}_{2}$ concentrations, the cumulative flux (the cumulation of instantaneous flux values) was a central parameter because it exhibits an abrupt change at such disturbances. In the present study, an average of $14 \pm 7 \%$ (mean $\pm \mathrm{SE}$, range: 0 to $22 \%$ ) of the recorded data were regarded as 'bad data' and were rejected from the analysis. For further information on eddy-correlation data processing and quality control, see Berg et al. (2003, 2009).

We have expressed all flux measurements in mmol $\mathrm{m}^{-2} \mathrm{~h}^{-1}$, while values extrapolated to cover the diel cycle are expressed as mmol m $\mathrm{m}^{-2} \mathrm{~d}^{-1}$. We chose this to clarify the temporal scale on which the benthic productivity is expressed and to facilitate extrapolation from diurnal/nocturnal to $24 \mathrm{~h}$ time scales. Values are presented as mean $\pm \mathrm{SE}$.

\section{RESULTS}

\section{Parallel $\mathrm{O}_{2}$ microprofiles, core incubations and eddy fluxes at $\mathrm{Stn} 1$}

We selected one of the few sites along the coastline of the Godthaabsfjord where it is possible to retrieve sediment ( $\mathrm{Stn} 1$ ), to evaluate how $\mathrm{O}_{2}$ exchange derived from the eddy correlation approach compared with values obtained by more traditional techniques. The sediment was cohesive sandy mud with a surface $(0-1.0 \mathrm{~cm})$ porosity of $0.78 \pm 0.01(\mathrm{n}=5)$ and an $\mathrm{O}_{2}$ penetration depth of $2.3 \pm 0.1 \mathrm{~mm}(\mathrm{n}=15)$, as measured in recovered sediment cores. The benthic fauna was dominated by sediment-dwelling polychaetes that accounted for $>70 \%$ of the total faunal abundance. However, their biomass was exceeded by small bivalves (mainly Macoma calcarea) and medium-sized sea urchins Strongylocentrotus droebachiensis (Table 2). The diffusive $\mathrm{O}_{2}$ exchange (DOE) as calculated from microprofiles measured in darkness was $-1.1 \pm 0.1 \mathrm{mmol} \mathrm{m}^{-2} \mathrm{~h}^{-1}(\mathrm{n}=15)$, while the total $\mathrm{O}_{2}$ exchange (TOE) measured in cores incubated in darkness amounted to $-1.6 \pm 0.1 \mathrm{mmol} \mathrm{m}^{-2} \mathrm{~h}^{-1}(\mathrm{n}=5)$. Selecting data obtained during darkness from the in situ eddy correlation $\mathrm{O}_{2}$ exchange (EOE) measurements provided an average $\mathrm{O}_{2}$ exchange of $-2.0 \pm$ $0.2 \mathrm{mmol} \mathrm{m}^{-2} \mathrm{~h}^{-1}(\mathrm{n}=61)$. Rates derived from the different approaches tend to reflect a gradual increase in benthic $\mathrm{O}_{2}$ exchange with increasing encompassed area at the study site (Fig. 3). However, a Mann-Whitney $U$-test revealed that while DOE was significantly lower than TOE and EOE ( $p<0.05)$, the TOE and EOE were not significantly different $(\mathrm{p}=0.09)$. 
Table 2. Mean $( \pm \mathrm{SD}$ ) density and biomass (ash free dry weight, AFDW) of macrofauna as estimated from van Veen grab samples (Stn 1, n = 3) and underwater photographs (Stns 2 to $5, \mathrm{n}=10$ to 20). Sea urchin: Strongylocentrotus droebachiensis; sea cucumber: Psolus fabricii; nd: no data

\begin{tabular}{|c|c|c|c|}
\hline Stn & Taxon & $\begin{array}{l}\text { Density } \\
\text { (ind } \mathrm{m}^{-2} \text { ) }\end{array}$ & $\begin{array}{c}\text { Biomass } \\
\text { (g AFDW m }{ }^{-2} \text { ) }\end{array}$ \\
\hline 1 & $\begin{array}{l}\text { Polychaeta } \\
\text { Bivalvia } \\
\text { Crustacea } \\
\text { Echinodermata (total) } \\
\text { Sea urchin } \\
\text { Others }\end{array}$ & $\begin{aligned} 3147 & \pm 707 \\
497 & \pm 337 \\
220 & \pm 66 \\
160 & \pm 131 \\
16.7 & \pm 5.8 \\
453 & \pm 323\end{aligned}$ & $\begin{aligned} 5.5 & \pm 2.2 \\
46.9 & \pm 79 \\
0.2 & \pm 0.2 \\
19.8 & \pm 8.5 \\
17.3 & \pm 6.5 \\
1.9 & \pm 1.7\end{aligned}$ \\
\hline 2 & $\begin{array}{l}\text { Sea urchin } \\
\text { Others }\end{array}$ & $\begin{aligned} 192.5 & \pm 61.9 \\
0.4 & \pm 0.7\end{aligned}$ & $\begin{array}{l}20.9 \pm 6.7^{\mathrm{a}} \\
\text { nd }\end{array}$ \\
\hline 3 & $\begin{array}{l}\text { Sea urchin } \\
\text { Others }\end{array}$ & $\begin{array}{r}19.0 \pm 8.1 \\
0.5 \pm 0.7\end{array}$ & $\begin{array}{l}32.5 \pm 13.8^{\mathrm{a}} \\
\text { nd }\end{array}$ \\
\hline 4 & $\begin{array}{l}\text { Sea urchin } \\
\text { Others }\end{array}$ & $\begin{array}{c}25.1 \pm 11.1 \\
3.1 \pm 2.4\end{array}$ & $\begin{array}{c}43.0 \pm 19.1^{\mathrm{a}} \\
\text { nd }\end{array}$ \\
\hline 5 & $\begin{array}{l}\text { Sea urchin } \\
\text { Sea cucumber }\end{array}$ & $\begin{array}{r}3.7 \pm 1.5 \\
22.6 \pm 8.1\end{array}$ & $\begin{array}{l}6.3 \pm 2.6^{\mathrm{a}} \\
\text { nd }\end{array}$ \\
\hline $\begin{array}{l}{ }^{a} \mathrm{Bic} \\
\text { on } \mathrm{t} \\
\text { spec }\end{array}$ & $\begin{array}{l}\text { hass estimated from abl } \\
\text { e photos along with ave } \\
\text { mens at the respective }\end{array}$ & $\begin{array}{l}\text { andance and si } \\
\text { rage individua } \\
\text { sites }\end{array}$ & $\begin{array}{l}\text { ze distribution } \\
\text { l biomass of }\end{array}$ \\
\hline
\end{tabular}

A total of 3 eddy deployments were carried out at Stn 1. Deployment 4 provided only 3 consecutive burst values of $1.5,4.9$, and $2.0 \mathrm{mmol} \mathrm{m}^{-2} \mathrm{~h}^{-1}$ before the $\mathrm{O}_{2}$ sensor broke. The values were obtained at an almost constant ambient light level of $\sim 250 \mu \mathrm{mol}$ photons $\mathrm{m}^{-2} \mathrm{~s}^{-1}$ and at an average ambient horizontal flow velocity of $\sim 2.4 \mathrm{~cm} \mathrm{~s}^{-1}$ (these values were included in the assessment of the benthic primary production, see 'Eddy flux measurements across complex benthic substrates'). The 2 other deployments at Stn 1 were obtained at lower light levels but provided longer time series and reflected extensive short-term variations in the EOE as exemplified in Fig. 4. The EOE was normally distributed around the mean, and variations did not show any direct relation to any single of the main controls that generally are considered to affect benthic $\mathrm{O}_{2}$ exchangelight availability, bottom-water $\mathrm{O}_{2}$ concentration and horizontal flow velocity-nor was there a clear relation to the direction of the current (data not shown). However, high horizontal flow velocities around dusk did coincide with maximum $\mathrm{O}_{2}$ uptake rates. Minimum $\mathrm{O}_{2}$ uptake (and $\mathrm{O}_{2}$ release) generally coincided with daytime measurements (Fig. 4). The variations in EOE are clearly regulated by the interplay of several variables that change on different time scales (see 'Discussion').

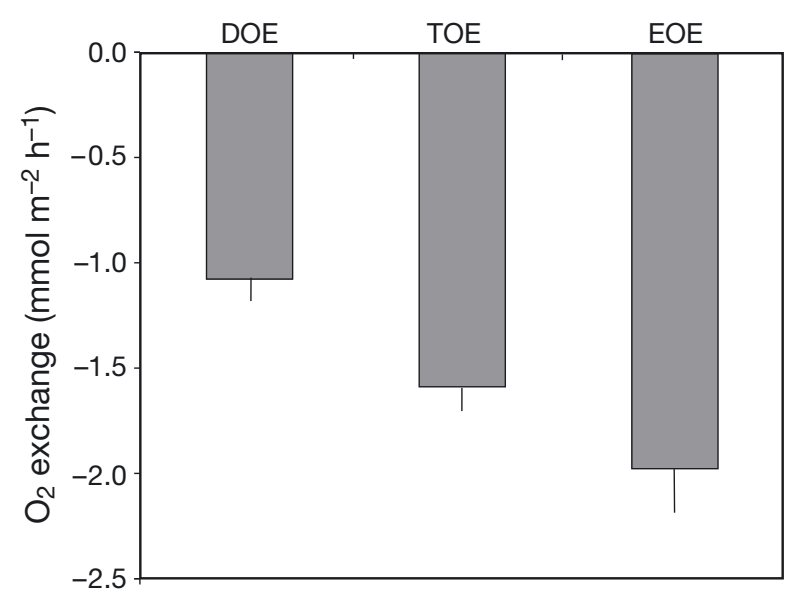

Fig. 3. Average $\mathrm{O}_{2}$ exchange at Stn 1 quantified in darkness (photosynthetically active radion: $<10$ photons $\mathrm{m}^{-2} \mathrm{~s}^{-1}$ ) from microelectrode profiles (DOE), total core incubations (TOE) and in situ eddy correlation (EOE). Error bars indicate SE; $\mathrm{n}=15,5,61$ for DOE, TOE and EOE, respectively
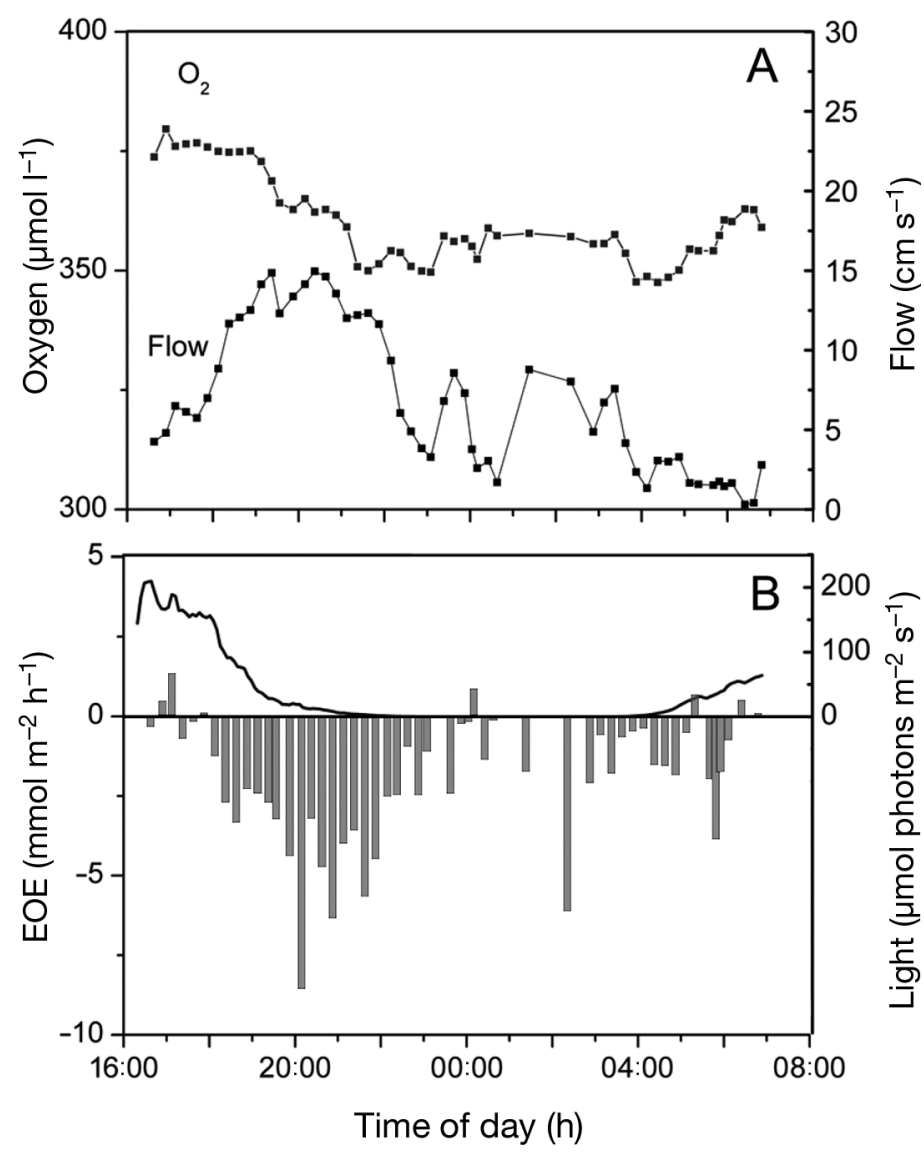

Fig. 4. Variations at Stn 1 (Deployment 3) in (A) bottom-water $\mathrm{O}_{2}$ concentration and horizontal flow velocities along with (B) light availability and eddy correlation $\mathrm{O}_{2}$ exchange (EOE) in the respective $14.5 \mathrm{~min}$ bursts 

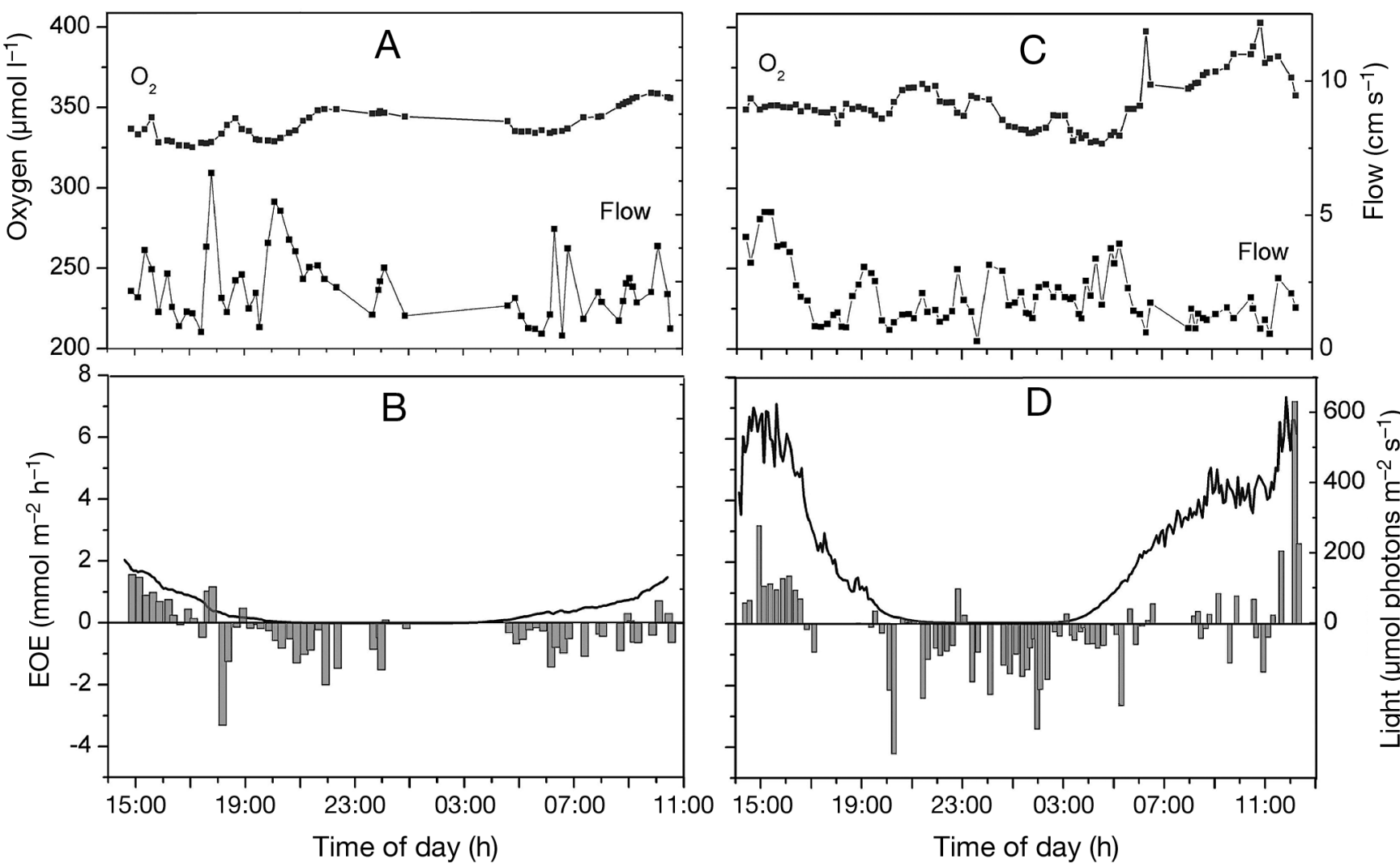

Fig. 5. Oxygen concentration and horizontal velocities at (A) Stn 3 and (C) Stn 4 along with (B,D) light availability and eddy correlation $\mathrm{O}_{2}$ exchange (EOE) in the respective 14.5 min bursts for both stations

\section{Eddy flux measurements across complex benthic substrates}

At stations where the seabed consisted of rocks, stones and consolidated sand (Stns 2 to 4 ), the eddy correlation was the only possible way to measure benthic $\mathrm{O}_{2}$ exchange. The EOE of these substrates also exhibited extensive short-term variation (Fig. 5). However, in general, periods with benthic $\mathrm{O}_{2}$ release prevailed during daytime while maximum $\mathrm{O}_{2}$ uptake rates were encountered at dusk or during nighttime (Fig. 5). While the average dark $\mathrm{O}_{2}$ uptake for Stns 2 and 3 was similar to the soft sediment at Stn 1, Stn 4 exhibited lower rates $(\mathrm{p}<0.05)$ (Table 3$)$. For logistic and safety reasons we had to recover and re-deploy the instrumentation during the middle of the day-a procedure that took 2 to $5 \mathrm{~h}$. Due to $\mathrm{O}_{2}$ sensor breakage and deployment constrains, measurements during periods of maximum light were few, but in all instances average daytime measurements reflected a significantly

Table 3. Mean eddy correlation-derived $\mathrm{O}_{2}$ exchange (EOE) rates (mean $\pm \mathrm{SE}$ ). No weighing of EOE data was performed (columns 2 and 3). Benthic primary production during $16 \mathrm{~h}$ of light was estimated by extrapolation from measurements of $\mathrm{O}_{2}$ release rates accounting for the incoming light during deployment (see 'Eddy flux measurement across complex benthic substrates' for details)

\begin{tabular}{|c|c|c|c|c|c|c|c|c|c|c|}
\hline \multirow[t]{2}{*}{ Stn } & \multicolumn{2}{|c|}{$\begin{array}{c}\mathrm{O}_{2} \text { exchange (EOE) } \\
\left(\mathrm{mmol} \mathrm{m}^{-2} \mathrm{~h}^{-1}\right)\end{array}$} & \multicolumn{2}{|c|}{$\begin{array}{l}\text { Time period }^{\mathrm{a}} \\
(\mathrm{h})\end{array}$} & \multirow[t]{2}{*}{$\begin{array}{c}\text { Irradiance }^{b} \\
(\%)\end{array}$} & \multicolumn{2}{|c|}{$\begin{array}{c}\text { Est. } \mathrm{O}_{2} \text { exchange } \\
\left(\mathrm{mmol} \mathrm{m}^{-2} \mathrm{~d}^{-1}\right)\end{array}$} & \multirow[t]{2}{*}{$\begin{array}{l}\text { Primary prod. }{ }^{\mathrm{c}} \\
\left(\mathrm{mmol} \mathrm{m}^{-2} \mathrm{~d}^{-1}\right)\end{array}$} & \multicolumn{2}{|c|}{$\begin{array}{l}\text { Bursts } \\
\text { (n) }\end{array}$} \\
\hline & Night & Day & Night & Day & & Day & Total & & Night & Day \\
\hline $1^{\mathrm{d}}$ & $-2.0 \pm 0.2$ & $-1.6 \pm 0.3$ & $8,0,8$ & $5.6,0.8,9.3$ & 22.5 & -3.6 & -19.6 & 27.5 & 63 & 66 \\
\hline 2 & $-1.3 \pm 0.2$ & $-0.7 \pm 0.3$ & 8 & 6.0 & 26.4 & 5.5 & -4.9 & 26.2 & 26 & 23 \\
\hline $3^{e}$ & $-1.9 \pm 0.2$ & $0.3 \pm 0.2$ & 8,8 & $0.8,14.6$ & 80.6 & 6.9 & -8.3 & 37.1 & 48 & 58 \\
\hline 4 & $-0.7 \pm 0.1$ & $-0.1 \pm 0.1$ & 8 & 10.1 & 56.5 & 5.2 & -0.4 & 17.5 & 17 & 41 \\
\hline $5^{f}$ & $-1.2 \pm 0.1$ & - & - & - & - & - & - & - & 42 & - \\
\hline
\end{tabular}

${ }^{\mathrm{a}}$ No. of hours during day (light $>10 \mu \mathrm{mol}$ photon $\mathrm{m}^{-2} \mathrm{~s}^{-1}$ ) and night covered by each deployment; ${ }^{\mathrm{b}}$ overall proportion of the daily light received during deployment; 'assuming $\mathrm{O}_{2}$ consumption is identical during day and night; ${ }^{\mathrm{d}} 3$ deployments; ${ }^{\mathrm{e}} 2$ deployments; ${ }^{\mathrm{f}} 17 \mathrm{~m}$ depth in the shadow of a high vertical cliff, max. light: $3 \mu \mathrm{mol}$ photon $\mathrm{m}^{-2} \mathrm{~s}^{-1}$ 
reduced $\mathrm{O}_{2}$ uptake (or $\mathrm{O}_{2}$ release) as compared to nighttime measurements $(\mathrm{p}<0.05)$ (Table 3). As most of our daytime measurements were recorded at relatively low light, we could not just linearly extrapolate the 'measured light EOE' to $16 \mathrm{~h}$ of light. Rather, we obtained a conservative estimate of the daily net benthic productivity (i.e. the daytime release of $\mathrm{O}_{2}$ ) using a weighted average where data obtained at the respective light levels were given proportional weight as evaluated from the light measurements. The estimates resolved an integrated $\mathrm{O}_{2}$ exchange during $16 \mathrm{~h}$ of light ranging from $-3.6 \mathrm{mmol} \mathrm{m}^{-2} \mathrm{~d}^{-1}$ at Stn 1 to $6.9 \mathrm{mmol} \mathrm{m}^{-2} \mathrm{~d}^{-1}$ at Stn 3 (Table 3). Integrating the benthic $\mathrm{O}_{2}$ exchange for $24 \mathrm{~h}$ (i.e. $16 \mathrm{~h}$ light and $8 \mathrm{~h}$ darkness), the benthic communities were in all cases net heterotrophic with a daily $\mathrm{O}_{2}$ uptake ranging between -0.4 to $-19.6 \mathrm{mmol}$ $\mathrm{m}^{-2} \mathrm{~d}^{-1}$ (Table 3).

Assuming that $\mathrm{O}_{2}$ consumption rate during night and day are the same, the differences in $\mathrm{O}_{2}$ exchange rates express the benthic primary production during daytime and amounted to values from 17.5 to $37.1 \mathrm{mmol}$ $\mathrm{m}^{-2} \mathrm{~d}^{-1}$ at the respective stations during $16 \mathrm{~h}$ of light (Table 3). The photosynthetic activity was mainly related to the activity of benthic diatoms, but for Stns 2 to 4 , where coralline algae covered up to 60 or $70 \%$ of the seabed (Fig. 2), they could have made a significant contribution to the system production (Roberts et al. 2002). The primary producers were extensively grazed by the epifauna dominated by the sea urchin Strongylocentrotus droebachiensis (Table 2).

\section{Eddy flux measurements along a vertical cliff}

The Godhaabsfjord, as most other deep fjords, is characterised by steep cliffs, often covered by suspension-feeding epifaunal communities taking advantage of the continuous supply of particulate organic material. To the extent that the prevailing current runs parallel to such cliffs, the eddy correlation principle should work equally well here as it does for the horizontal seabed. Continuous recordings of the instrument packages mounted directly on the wall with the ADV pointing towards the cliff face in general confirmed a correlation between variations in the flow velocity in the direction perpendicular to the cliff and the $\mathrm{O}_{2}$ concentration (Fig. 6). Consequently, cumulative $\mathrm{O}_{2}$ fluxes generally reflected a linear uptake during the respective bursts (data not shown). During the $\sim 12 \mathrm{~h}$ deployment performed at $\sim 17 \mathrm{~m}$ depth in the shadow of the high cliff, the maximum recorded light level was $3 \mu \mathrm{mol}$ photon $\mathrm{m}^{-2} \mathrm{~s}^{-1}$. The horizontal flow velocity (i.e. parallel to the cliff) was low ranging from 0.5 to $3.9 \mathrm{~cm} \mathrm{~s}^{-1}$ and there was no close relation between the EOE and flow velocity. However, maximum rates of $\mathrm{O}_{2}$ uptake coincided with maximum velocities measured towards the end of the deployment (Fig. 7). The entire cliff was densely covered with sea cucumbers and to a lesser extent with sea urchins (Table 2). The average $\mathrm{O}_{2}$ uptake of the community amounted to $1.2 \pm 0.1 \mathrm{mmol} \mathrm{m}^{-2} \mathrm{~h}^{-1}(\mathrm{n}=42)$. The cumulative average expressing the average EOE value of recordings at any given time quickly approached the overall average value (Fig. $7 \mathrm{C}$ ).

\section{DISCUSSION}

\section{Benthic primary production}

Our measurements indicate that the different seabeds were net heterotrophic during the study period, but they also reflected a significant benthic primary production ranging from 17.5 to $37.1 \mathrm{mmol} \mathrm{O}_{2}$ $\mathrm{m}^{-2} \mathrm{~d}^{-1}$ (average: $27.2 \mathrm{mmol} \mathrm{O} \mathrm{m}^{-2} \mathrm{~d}^{-1}$ ). These values have to be regarded as minimum values, as we only conservatively extrapolated the measured daytime values. Further, identical day- and nighttime $\mathrm{O}_{2}$ consumption was assumed, but detailed microsensor measurements have documented that daytime $\mathrm{O}_{2}$ consumption typically exceeds nighttime $\mathrm{O}_{2}$ consumption by a factor of 1.4 to 1.8 (Fenchel \& Glud 2000). This observation is mainly a result of efficient microbial turnover of leaking photosynthesates and deeper $\mathrm{O}_{2}$ penetration during the daytime (Epping \& Jørgensen 

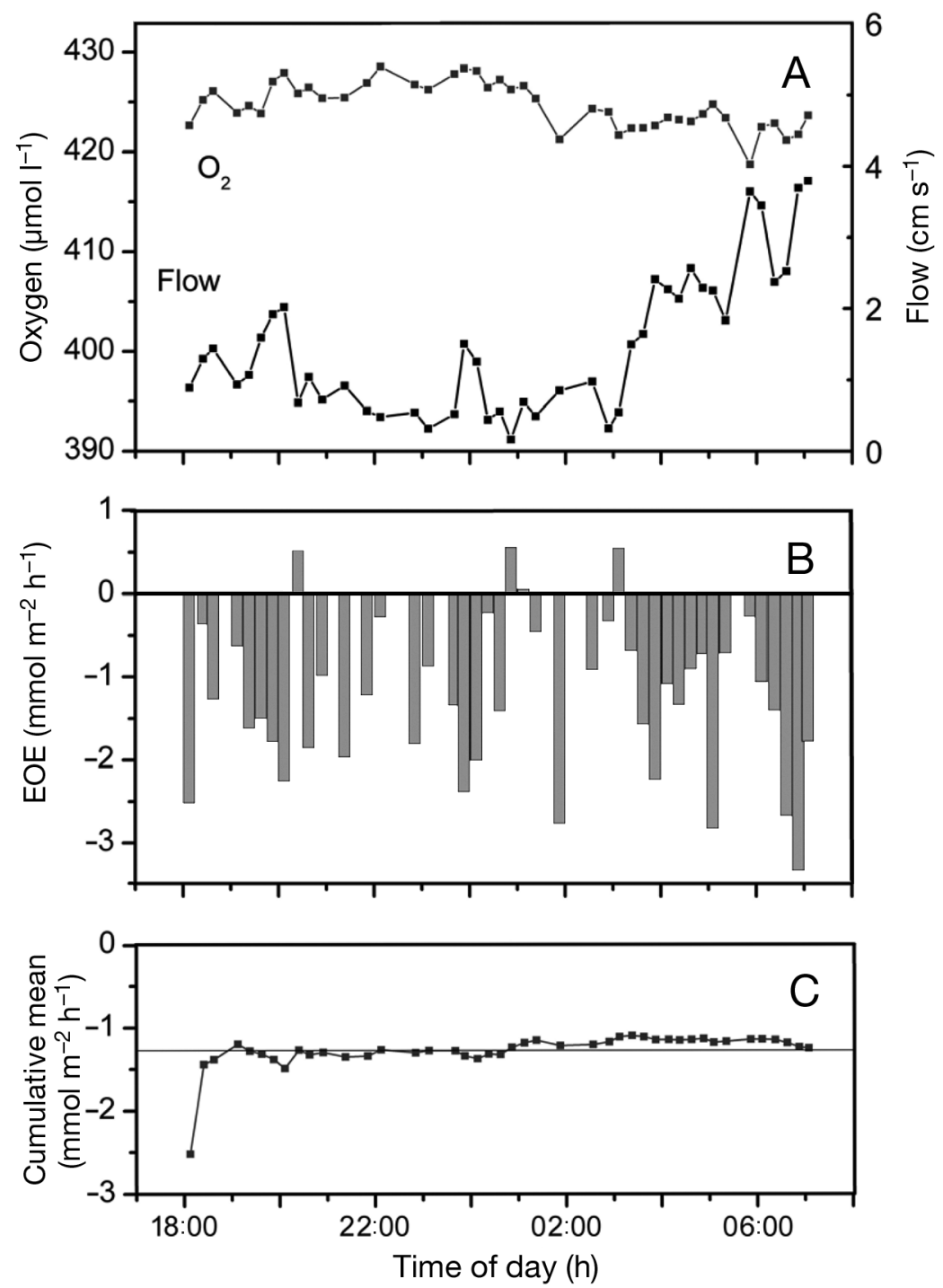

Fig. 7. (A) Oxygen concentration and horizontal flow velocities at Stn 5 and (B) mean $\mathrm{O}_{2}$ exchange rate as derived from eddy correlation (EOE) in the respective 14.5 min bursts. (C) Cumulative mean at the time points of each burst in (B) along with the overall mean (horizontal line in C)

1996, Fenchel \& Glud 2000, Tang \& Kristensen 2007). The fact that we often observed maximum $\mathrm{O}_{2}$ uptake rates just at dusk, when photosynthetic activity ceased, indeed suggests that a labile pool of photosynthesates is quickly utilized and exhausted at the onset of darkness. Resolving the benthic primary production from the net $\mathrm{O}_{2}$ exchange rates therefore only provides a minimum value. Despite this, values are similar to that of the gross pelagic primary production measured just before and after our campaign in the central parts of the $\sim 600 \mathrm{~m}$ deep fjord; the integrated gross primary production of the $\sim 50 \mathrm{~m}$ deep euphotic zone at May 15 and June 17, 2009 amounted to 35 and $15 \mathrm{mmol} \mathrm{O}_{2} \mathrm{~m}^{-2}$ $\mathrm{d}^{-1}$, respectively (Juul-Pedersen et al. 2010). The measurements suggest that the rugged seabed along such coastlines hosts a significant primary production driven by micro- and coralline algae that contribute significantly to sustaining microbial heterotrophic activity and the larger grazers of this zone.

\section{Benthic $\mathrm{O}_{2}$ consumption in shallow water}

The difference between $\mathrm{O}_{2}$ exchange as derived from porewater profiles and sediment core incubations has often been used to assess the non-diffusive $\mathrm{O}_{2}$ exchange, which for the most part has been ascribed to faunal activity (Archer \& Devol 1992, Meile \& van Cappellen 2003, Glud 2008). However, it has also been documented that small core incubations tend to exclude larger fauna species and consequently underestimate the true, fauna-mediated $\mathrm{O}_{2}$ exchange (Glud \& Blackburn 2002, Glud et al. 2003). These observations could not be confirmed by the measurements at Stn 1 . The EOE does exhibit extensive short-term variations; thus, the average values are bracketed by a large SE or SD, and even though the value exceeded the small core (inner diameter: $5.3 \mathrm{~cm}$ ) incubations by $25 \%$, they were not significantly different. This is despite the fact that EOE encompassed the effects of larger in- and epifauna specimens such as Macoma calcarea, Mya neoovata and Strongylocentrotus droebachiensis, which are not represented in the core incubations. Overall, the faunamediated $\mathrm{O}_{2}$ uptake (EOE - DOE) averaged $0.9 \mathrm{mmol} \mathrm{m}^{-2} \mathrm{~h}^{-1}$, equivalent to $46 \%$ of the integrated $\mathrm{O}_{2}$ uptake derived from eddy correlation. Both the absolute value and the relative proportion of faunamediated $\mathrm{O}_{2}$ uptake align well with similar estimates derived from concurrent in situ deployments of largesized chambers and microprofilers in shallow water soft sediments (Glud 2008). Currently, there only exist 2 studies with concurrent in situ measurements of large in situ chambers and eddy correlation. They suggest that in soft-bottom cohesive sediments and where the in situ fauna is proportionally represented during chamber incubation, the 2 approaches provide similar results (Berg et al. 2003, 2009). However, in more complex environments characterized by advective porewater transport or dominated by megafauna, large differences can be observed (Berg \& Huettel 2008).

The EOE as measured on hard-bottom stations (i.e. Stns 2 to 4 ) was surprisingly high considering little sed- 
iment accumulation. Actually, the $\mathrm{O}_{2}$ uptake measured in darkness scales with chamber measurements in many shallow-water, carbon- and fauna-rich depositional sediments (Moodley et al. 1998, Laursen \& Seitzinger 2002, Rowe et al. 2002, Glud et al. 2003). In recent years, there has been increasing evidence that despite low carbon content, permeable sands can have high $\mathrm{O}_{2}$ turnover rates due to an efficient entrapment and recycling of particulate carbon (Huettel et al. 1996, 2007, Cook et al. 2007). The capability for such sands to work as biocatalytic filters facilitating an efficient carbon turnover does, however, require an occasional wave-induced 'resetting' as they otherwise gradually consolidate and clog up (Huettel \& Webster 2001). We cannot assess the permeability of the complex substrates of the present study (as recovery is impossible), but the fact that the seafloor at Stns 2 to 4 consists of stones covered with slow-growing coralline algae or dense coverage of shells suggests that the intervening sediment rarely is resuspended or redistributed. Even though material can be trapped in the complex topography, most of the $\mathrm{O}_{2}$ consumption is probably occurring in biofilms at the substrate surface when degrading locally produced organic material. The main macrofauna grazers at these sites are Strongylocentrotus droebachiensis (Table 2) that traverse over the surface rasping stones and ingesting the diatom-enriched surface sediment. In Kobbefjord (see Fig. 1), the average annual carbon demand of the $S$. droebachiensis community on the basis of growth rates (including gonad production) has been estimated previously and amounted to $\sim 61 \mathrm{~g} \mathrm{C} \mathrm{m}^{-2} \mathrm{yr}^{-1}$ (Blicher et al. 2009). Assuming that $30 \%$ of the ingested carbon is respired (Miller \& Mann 1973) with a respiratory coefficient of 0.7 (Grebmeier et al. 2006), the average contribution of the community at 0 to $10 \mathrm{~m}$ water depth amounted to $0.25 \mathrm{mmol} \mathrm{O}_{2} \mathrm{~m}^{-2} \mathrm{~h}^{-1}$ equivalent to between 19 and $35 \%$ of the nighttime $\mathrm{O}_{2}$ uptake at Stns 2 to 4 (Table 3). Apart from the respiratory $\mathrm{O}_{2}$ demand of Strongylocentrotus droebachiensis, the considerable faecal production of these animals, amounting to $60 \%$ of their ingestion (Miller \& Mann 1973), must stimulate a patchy microbial-driven remineralization leading to further $\mathrm{O}_{2}$ consumption. Clearly, these complex benthic substrates host dynamic communities with high carbon turnover rates. The average rate equates with those of soft sediments (Glud 2008), but the remineralization is largely fuelled by local benthic primary production.

Whereas the communities at Stns 1 to 4 presumably obtain a significant fraction of their carbon from local benthic primary production, the filter-feeding sea cucumbers of Stn 5 must depend on a pelagic food source that is advected to the community. Oxygen uptake of the epifauna-covered cliff is similar to that of the hard-bottom stations (i.e. Stns 2 to 4). In principle, the respiration rates of Psolus fabricii at the given environmental conditions could be assessed from the density and the EOE, but such an estimate would be confounded by $\mathrm{O}_{2}$ consumption of biofilms and other epifauna. Nevertheless, the respiratory activity of the epifauna per $\mathrm{m}^{2}$ (including any microbial biofilms) on a $24 \mathrm{~h}$ basis is only slightly less than that of the daily pelagic primary production of the entire $50 \mathrm{~m}$ deep photic zone during the same period (i.e. 1.3 to $2.9 \mathrm{mmol}$ $\mathrm{m}^{2} \mathrm{~h}^{-1}$; Juul-Pedersen et al. 2010). This demonstrates that the epifauna-covered cliffs of the narrow fjords can efficiently graze on the pelagic production, but their relative importance will obviously depend on the geometry of the fjords and on the frequency of such dense epifaunal assemblages - a topic for further studies.

\section{Oxygen exchange rates as derived from eddy correlation}

The introduction of the eddy correlation technique to aquatic research allows quantification of $\mathrm{O}_{2}$ exchange across benthic interfaces that in praxis are impossible to investigate with chambers and microelectrode profiling. Further, the approach non-invasively integrates $\mathrm{O}_{2}$ exchange of a large area (Berg et al. 2007). However, the actual location and size of this measuring area or footprint in a dynamic environment can be difficult to define. With constant changes in the direction and velocity of flow over a highly heterogeneous seabed, the derived $\mathrm{O}_{2}$ exchange is bound to exhibit high variation. Further, water bodies passing the measuring volume may express an $\mathrm{O}_{2}$ balance that has accumulated over time scales that are longer than the temporal resolution of the bursts. For instance, water that has been isolated over a highly $\mathrm{O}_{2}$ consuming (or producing) patch of the seabed and then advected into the measuring area results in a transient unrepresentative high (or low) $\mathrm{O}_{2}$ exchange rate for the measuring area. Derived fluxes may even temporarily exhibit the opposite sign of the overall average flux. This is exemplified by the incubations at the vertical cliff where the derived $\mathrm{O}_{2}$ exchange rate varied between 0.6 and $-3.5 \mathrm{mmol} \mathrm{m}^{-2} \mathrm{~h}^{-1}$ during the $\sim 12 \mathrm{~h}$ incubation (Fig. 7). However, the cumulative average (i.e. the average exchange rate obtained at any given time after deployment) quickly approached the overall average of $-1.2 \mathrm{mmol} \mathrm{m}^{-2} \mathrm{~h}^{-1}$, but it never reached a true steady level (Fig. 7C). This is presumably a consequence of the constant changes in a free flow velocity and particle density, which could affect fauna activity. For coastal environments in general, the ever-changing free flow velocity (or better turbulent dissipation 
energy) will regulate the diffusive boundary layer thickness, which again will affect the benthic $\mathrm{O}_{2}$ distribution. Consequently, the benthic $\mathrm{O}_{2}$ exchange rates will exhibit a high degree of variability, reflecting concurrent changes in the local hydrodynamics (Lorke et al. 2003, Røy et al. 2004, Glud et al. 2007). For heterogeneous environments it is therefore imperative to obtain long time series in order to resolve the correct average $\mathrm{O}_{2}$ exchange. Even though eddy-derived fluxes can reflect distinct changes in environmental controls like light or flow velocity (Berg \& Huettel 2008), the interplay of several controls and the general short-term variations in the eddy flux can mask such relations.

The eddy correlation approach is in many ways superior to other approaches for resolving the benthic $\mathrm{O}_{2}$ exchange. However, from a practical point of view one key issue is frequent sensor breakage, and for future research the development of more robust sensors would be highly advantageous. Sturdy fastresponding minielectrodes with outside diameters ranging from 0.1 to a few millimetres have been used for benthic investigations (Wenzhöfer et al. 2000, de Beer et al. 2005, Cook et al. 2007) and robust optodes have also proven useful for in situ operation in different benthic environments (Glud et al. 1999, Wenzhöfer et al. 2001). Novel, highly $\mathrm{O}_{2}$-sensitive chemiluminescent indicator complexes (Mayr et al. 2009) have potential for a new generation of fast responding minioptodes that could provide a sturdy and cheap alternative to electrochemical sensors for eddy correlation $\mathrm{O}_{2}$ measurements.

Acknowledgements. The study was financially supported by the National Environmental Research Council (NERC; NE/ F012691/1), the Commission for Scientific Research in Greenland (KVUG; GCRC6507), the National Science Foundation in the USA (OCE-0221259, OCE-0536431) and The Ministry of Culture, Education and Churches (KIIP). A. Glud and A. Reynolds are thanked for skillful microelectrode fabrication and F. Heinrich for assistance in the field. We appreciate 4 constructive reviewers who all helped to improve the quality of the manuscript.

\section{LITERATURE CITED}

Archer D, Devol A (1992) Benthic oxygen fluxes on the Washington shelf and slope: a comparison of in situ microelectrode and chamber flux measurements. Limnol Oceanogr 37:614-629

Berg P, Huettel M (2008) Monitoring the sea-floor using the non-invasive eddy correlation technique: integrated benthic exchange dynamics. Oceanography 21:164-167

Berg P, Røy H, Janssen F, Meyer V, Jørgensen BB (2003) Oxygen uptake by aquatic sediments measured with a novel non-invasive eddy-correlation technique. Mar Ecol Prog Ser 261:75-83

Berg P, Røy H, Wiberg PL (2007) Eddy correlation flux mea- surements: the sediment surface area that contributes to the flux. Limnol Oceanogr 52:1672-1684

Berg P, Glud RN, Hume A, Stahl H, Oguri K, Meyer V, Kitazato H (2009) Eddy correlation measurements of oxygen uptake in deep ocean sediments. Limnol Oceanogr Methods 7:576-584

> Blicher ME, Sejr MK, Rysgaard S (2009) High carbon demand of dominant macrozoobenthic species indicates their central role in ecosystem carbon flow in a sub-Arctic fjord. Mar Ecol Prog Ser 383:127-140

Boertmann D, Mosbech A, Schiedek D, Johansen K (eds) (2009) The eastern Baffin Bay. A preliminary strategic environmental impact assessment of hydrocarbon activities in the KANUMAS West area. NERI Tech Rep No 720. National Environmental Research Institute, Aarhus University, Roskilde

Broecker WS, Peng TH (1974) Gas exchange rates between air and sea. Tellus 26:21-35

Cook PLM, Wenzhöfer F, Glud RN, Janssen F, Huettel M (2007) Benthic solute exchange and carbon mineralization in two shallow subtidal sandy sediments: impact of advective porewater exchange. Limnol Oceanogr 52:1943-1963

> de Beer D, Wenzhöfer F, Ferdelman TG, Boehme SE and others (2005) Transport and mineralization rates in North Sea sandy intertidal sediments, Sylt-Rømø Basin, Waddensea. Limnol Oceanogr 50:113-127

Epping EHG, Jørgensen BB (1996) Light-enhanced oxygen respiration in benthic phototrophic communities. Mar Ecol Prog Ser 139:193-203

Fenchel T, Glud RN (2000) Benthic primary production and $\mathrm{O}_{2}-\mathrm{CO}_{2}$ dynamic in a shallow water sediment: spatial and temporal heterogeneity. Ophelia 53:159-171

Glud RN (2008) Oxygen dynamics of marine sediments. Mar Biol Res 4:243-289

Glud RN, Blackburn N (2002) The effect of chamber size on benthic oxygen uptake measurements: a simulation study. Ophelia 56:23-31

Glud RN, Klimant I, Holst G, Kohls O, Meyer V, Kuhl M, Gundersen JK (1999) Adaptation, test and in situ measurements with $\mathrm{O}_{2}$ micropt(r)odes on benthic landers. DeepSea Res 46:171-183

Glud RN, Gundersen JK, Røy H, Jørgensen BB (2003) Seasonal dynamics of benthic $\mathrm{O}_{2}$ uptake in a semi enclosed bay: importance of diffusion and fauna activity. Limnol Oceanogr 48:1265-1276

Glud RN, Berg P, Fossing H, Jørgensen BB (2007) Effect of the diffusive boundary layer (DBL) on the benthic mineralization and $\mathrm{O}_{2}$ distribution: a theoretical modelling exercise. Limnol Oceanogr 52:547-557

Glud RN, Eyre BD, Patten N (2008) Biogeochemical responses to coral mass spawning at the Great Barrier Reef: effects on respiration and primary production. Limnol Oceanogr 53:1014-1024

> Glud RN, Woelfel J, Karsten U, Kühl M, Rysgaard S (2009) Benthic microalgae production in the Arctic: applied methods and status of the current database. Bot Mar 52:559-571

> Grebmeier JM, Cooper LW, Feder HM, Sirenko BI (2006) Ecosystem dynamics of the Pacific-influenced Northern Bering and Chukchi Seas in the Amerasian Arctic. Prog Oceanogr 71:331-361

Gundersen JK, Ramsing NB, Glud RN (1998) Predicting the signal of oxygen microsensors from the physical dimensions, temperature, salinity and oxygen concentrations. Limnol Oceanogr 43:1932-1937

Hop H, Pearson T, Hegset E, Kovacs K and others (2002) The marine ecosystem of Kongsfjord, Svalbard. Polar Res 21: $167-208$ 
Huettel M, Webster IT (2001) Porewater flow in permeable sediments. In: Boudreau B, Jørgensen BB (eds) The benthic boundary layer. Oxford University Press, New York, NY, p 144-179

Huettel M, Ziebis W, Forster S (1996) Flow induced uptake of particulate matter in permeable sediments. Limnol Oceanogr 41:309-322

Huettel M, Cook P, Janssen F, Lavik G, Middelburg JJ (2007) Transport and degradation of a dinoflagellate bloom in permeable sublittoral sediment. Mar Ecol Prog Ser 340: 139-153

Jahnke RA, Nelson JR, Marinelli RL, Eckman JE (2000) Benthic flux of biogenic elements on the Southeastern US continental shelf: influence of pore water advective transport and benthic microalgae. Cont Shelf Res 20:109-127

Juul-Pedersen T, Rysgaard S, Batty P, Mortensen J and others (2010) The MarinBasis programme. In: Jensen LM, Rasch M (eds) Nuuk Ecological Research Operations, 3rd Annu Rep 2009. National Environmental Research Institute, Aarhus University, Roskilde

Kuwae T, Kamio K, Inoue T, Miyoshi E, Uchiyama Y (2006) Oxygen exchange flux between sediment and water in an intertidal sandflat, measured in situ by the eddycorrelation method. Mar Ecol Prog Ser 307:59-68

Laursen AE, Seitzinger SP (2002) The role of denitrification in nitrogen removal and carbon mineralization in MidAtlantic Bight sediments. Cont Shelf Res 22:1397-1416

Li YH, Gregory S (1974) Diffusion of ions in sea water and in deep-sea sediments. Geochim Cosmochim Acta 38: 703-714

> Lorke A, Muller B, Maerki M, Wuest A (2003) Breathing sediments: the control of diffusive transport across the sediment-water interface by periodic boundary-layer turbulence. Limnol Oceanogr 48:2077-2085

Mayr T, Borisov SM, Abel T, Enko B, Waich K, Mistlberger G, Klimant I (2009) Light harvesting as a simple and versatile way to enhance brightness of luminescent sensors. Anal Chem 81:6541-6545

McGinnis DF, Berg P, Brand A, Lorrai C, Edmonds TJ, Wuest A (2008) Measurements of eddy correlation oxygen fluxes in shallow freshwaters: towards routine applications and analysis. Geophys Res Lett 35:L04403, doi:10.1029/2007

Editorial responsibility: Paul Snelgrove, St. John's, Newfoundland, Canada
GL032747

> Meile C, van Cappellen P (2003) Global estimates of enhanced solute transport in marine sediments. Limnol Oceanogr 48: $777-786$

Middelburg JJ, Carlos CM, Gattuso JJ (2008) Respiration in coastal benthic communities. In: del Giorgio PA, Williams $\mathrm{PJ}$ le B (eds) Respiration in aquatic ecosystems. Oxford University Press, New York, NY, p 206-224

Miller R, Mann K (1973) Ecological energetics of the seaweed zone in a marine bay on the Atlantic coast of Canada. III. Energy transformations by sea urchins. Mar Biol 18: 99-114

> Moodley L, Heip CHR, Middelburg JJ (1998) Benthic activity in sediments of the northwestern Adratic Sea: sediment oxygen consumption, macro and meiofauna dynamics. J Sea Res 40:263-280

Revsbech NP (1989) An oxygen microelectrode with a guard cathode. Limnol Oceanogr 34:474-478

Revsbech NP, Jørgensen BB (1986) Microelectrodes and their use in microbial ecology. In: Marshall KC (ed) Advances in microbial ecology, Vol 9. Plenum Press, New York, NY, p 293-352

> Roberts RD, Kühl M, Glud RN, Rysgaard S (2002) Primary production of crustose coralline red algae in a high arctic fjord. J Phycol 38:273-283

Rowe GT, Kaegi MEC, Morse JW, Boland GS, Briones EGE (2002) Sediment community metabolism associated with continental shelf hypoxia, Northern Gulf Mexico. Estuaries 25:1097-1106

Røy H, Huettel M, Jørgensen BB (2004) Transmission of oxygen concentration fluctuations through the diffusive boundary layer overlying aquatic sediments. Limnol Oceanogr 49:686-692

Tang M, Kristensen E (2007) Impact of microphytobenthos and macrofauna on temporal variation of benthic metabolism in shallow coastal sediments. J Exp Mar Biol Ecol 349:99-112

Wenzhöfer F, Holby O, Glud RN, Nielsen HK, Gundersen JK (2000) In situ microsensor studies of a hydrothermal vent at Milos, Greece. Mar Chem 69:43-54

Wenzhöfer F, Holby O, Kohls O (2001) Deep penetrating benthic oxygen profiles measured in situ by oxygen optodes. Deep-Sea Res 48:1741-1755

Submitted: April 30, 2010; Accepted: August 27, 2010 Proofs received from author(s): October 5, 2010 